\title{
Life Satisfaction and Academic Performance of Elementary School Students
}

\author{
Ana Maria Nunes El Achkar \\ Vanessa Barbosa Romera Leme ${ }^{2}$ \\ Adriana Benevides Soares' \\ Maria Angela Mattar Yunes' \\ ${ }^{1}$ Universidade Salgado de Oliveira, Niterói, RJ \\ ${ }^{2}$ Universidade do Estado do Rio de Janeiro, Rio de Janeiro, RJ
}

\begin{abstract}
The study aimed to investigate the association of risk and protection factors in the academic performance and life satisfaction of elementary school students. Participants included 400 students of both sexes, aged between 11 and 17 years, and 26 female teachers from public and private schools in the state of Rio de Janeiro. The instruments were: Social Skills Inventory for Adolescents, Social Support Perception Scale, Brazilian Youth Questionnaire and Maslach Burnout Inventory. Main results showed that exposure to family violence by the students, emotional exhaustion and low professional achievement by the teachers contribute to a poor performance of students in school. Students with indicators of social support by the family and the community and of self-control skills presented higher life satisfaction. This study reveals contextual and personal variables that affect students' socio-emotional and academic development which prove subsidies for future interventions.

Keywords: academic achievement; life satisfaction; resilience; elementary school
\end{abstract}

Satisfação com a Vida e Desempenho Escolar de Estudantes do Ensino Fundamental

\begin{abstract}
Resumo
O estudo investigou a associação de fatores de risco e de proteção sobre o desempenho escolar e a satisfação com a vida de estudantes do Ensino Fundamental. Participaram 400 alunos de ambos os sexos, com idade entre 11 e 17 anos e 26 professoras de escolas públicas e particulares do estado do Rio de Janeiro. Os instrumentos utilizados foram: Inventário de Habilidades Sociais para Adolescentes; Escala de Percepção de Apoio Social; Questionário da Juventude Brasileira; Inventário de Burnout de Maslach. Os principais resultados mostraram que a exposição à violência na família pelos estudantes, exaustação emocional e baixa realização profissional das professoras contribuem para o baixo desempenho escolar dos estudantes. Alunos com indicadores de apoio social na família e comunidade e habilidades sociais de autocontrole apresentam maior satisfação com a vida. Os dados do estudo evidenciam variáveis contextuais e pessoais que afetam o desenvolvimento socioemocional e acadêmico dos estudantes, fornecendo subsídios para futuras intervenções.

Palavras-chave: desempenho escolar; satisfação com a vida; resiliência; ensino fundamental
\end{abstract}

\section{Satisfacción con la Vida y Desempeño Escolar de Estudiantes de la Enseñanza Primaria}

\begin{abstract}
Resumen
El estudio explotó la asociación de factores de riesgo y de protección sobre el desempeño escolar y la satisfacción con la vida de estudiantes de la Enseñanza Primaria. Participaron 400 alumnos de ambos sexos, con edades entre 11 y 17 años y 26 profesoras de escuelas públicas y privadas del Estado de Río de Janeiro. Los instrumentos utilizados fueron: Inventario de Habilidades Sociales para Adolescentes; Escala de Percepción de Apoyo Social; Cuestionario de la Juventud Brasileña; Inventario de Burnout de Maslach. Los principales resultados mostraron que la exposición a la violencia en la familia por los estudiantes, agotamiento emocional y baja realización profesional de las profesoras contribuyen para el bajo desempeño escolar de los estudiantes. Alumnos con indicadores de apoyo social en la familia y en la comunidad y habilidades de autocontrol presentan mayor satisfacción con la vida. Los datos del estudio evidencian variables contextuales y personales que afectan el desarrollo socioemocional y académico de los estudiantes, ofreciendo subsidios para futuras intervenciones.

Palabras clave: desempeño escolar; satisfacción con la vida; resiliencia; enseñanza primaria.
\end{abstract}

School performance and life satisfaction are both multidetermined phenomena. Therefore, studies that seek to identify and discus the influence of risk and protection factors in students' lives are increasingly common (Coimbra \& Fontaine, 2015; Masten, 2014).
Conceptions of risk and protection integrate researchers' concerns about resilience processes that can be understood as the ability of a dynamic system to adapt positively to threats that impair its development (Masten, 2014). 
In the evaluation of resilience processes in an educational context most studies focus on normative and external criteria to infer about students' adjustment such as good school performance (Coimbra \& Fontaine, 2015). This can be understood as the students' ability to present and express what has been learned and acquired in terms of academic knowledge in the course of teaching-learning processes (Perrenoud, 2003). Socio-emotional aspects in turn influence school outcomes and vice versa (Berger, Alcalay, Torretti, \& Milicic, 2011; Long \& Huebner, 2014). Thus, it is pertinent to consider subjective aspects of individuals in the face of adversities (Berger et al., 2011; Coimbra \& Fontaine, 2015) when investigating resilience processes in the school environment.

In this sense, along with school performance, satisfaction with life can be a social-affective indicator to understand how students face difficulties of their daily academic life. Satisfaction with life, established as a cognitive aspect of subjective well-being, is defined as the individual assessment of the positive aspects of one's own life as a whole in specific domains, such as family, circle of friends and school life (Long \& Huebner, 2014). Students with school difficulties may present lower life satisfaction, because they are more likely to develop depression and anxiety caused by high levels of frustration, feelings of lack of control and predictability due to school difficulties (Berger et al., 2011). The school's results reflect not only characteristics of the school context, but include also influences from family, friends, and the community (Long \& Huebner, 2014), as well as public policies (Dazzani, Cunha, Luttigards, Zucoloto, \& Santos, 2014).

Studies have shown that coercion and physical and/or psychological violence in the family environment may be associated with negative outcomes in school settings and impair learning (Coohey, Rennera, Huab, Zhangc, \& Whitneyd, 2011; Pacheco, Irigaray, Werlang, Nunes, \& Argimon, 2014). Intrafamily violence impairs the formation of healthy relationships with peers and teachers, and may lead to a low academic performance that characterizes many students who are victims of abuse (Ho \& Cheung, 2010). Exposure to violence in different contexts, such as in the family, school and community, leads to higher levels of internalizing symptoms (e.g., depression and anxiety) and externalizing ones (e.g. aggression and bullying), lower levels of mental health, besides low school performance and satisfaction with life (Devries et al., 2014;
Hammig \& Jozkowski, 2013; Ho \& Cheung, 2010; Silva \& Dell’Aglio, 2016).

In addition, schools today face difficult challenges, such as the absence of public policies and archaic didactic-pedagogical work that undermine the continuing education of educators and the promotion of socio-emotional and academic competences that are essential for students' learning and permanence in school (Dazzani et al., 2014; Silva, Bolsoni-Silva, Rodrigues, \& Capellini, 2015). Thus, it is not uncommon for teachers to be one step away from stress or Burnout Syndrome. The syndrome refers to persistent emotional and/or physical fatigue and fatigue related to work situations, characterized by emotional pressure due to intense involvement with people for long periods (Maslach, Schaufeli, \& Leiter, 2001).

Burnout syndrome is one of the main causes of teachers' leave of absence from work and can lead to medium- and long-term damage to the physical and mental health of educators (Dieh \& Marin, 2016). In addition, several studies indicate that Burnout not only reduces teachers' awareness of their personal and professional competencies, but also negatively impacts the relationship with their students (Achkar, Leme, Soares, \& Yunes, 2016; Koga et al., 2015; Silva et al., 2015). Thus, the Burnout Syndrome is a risk factor for the healthy development of both teachers and students and it hinders the expression of resilience processes in the school context. Although few studies investigate the consequences of this syndrome on academic outcomes and student well-being, they all agree on the driving and protective force of affective and welcoming relationships, often attributed only to family environments. It is important to emphasize that school and family are important development settings that can be classified as risk or protection environments, depending on the conditions of their interactional and social dynamics (Juliano \& Yunes, 2014; Masten, 2014).

Due to the innumerable adversities that affect the permanence of students in school during the years of basic education, social skills are the focus of many studies, since they may act as protective factors for students who present interpersonal and school difficulties (Fernandes, Leme, Elias, \& Soares, 2018; Marturano $\&$ Pizato, 2015) and they can be relevant in promoting resilience processes in the school context (Coimbra \& Fontaine, 2015).

Social skills are defined as behaviors valued in a particular culture and historical moment and contribute to positive interpersonal relationships, as well as 
for the maintenance and/or enhancement of Human Rights (Del Prette \& Del Prette, 2010). Studies have shown associations between higher levels of social skills of students both with life satisfaction and good school results (Caemmerer \& Keith, 2015; FrançaFreitas, Del Prette, \& Del Prette, 2017; Fernandes et al., 2018; Ronen, Hamama, Rosenbaum, \& MishelyYarlap, 2016).

The relationship with the diversity of behaviors, values and knowledge present in the family, school and community environments provide the main sources of social support for the promotion of cognitive and socio-affective development of students during elementary education (Fernandes et al., 2018; Marturano \& Pizato, 2015; Olsson, Hagekull, Giannotta, \& Ahalander, 2016). The perception of social support refers to how the person relates with and is perceived supported by significant others (Vaux et al., 1986). When students receive the necessary social support from their family, school and other community settings, school success occurs despite adversities (Alves \& Dell'Aglio, 2015).

Thus, the perception of social support can make it easier for students to adapt to changes during the transitions they go through at various levels of education and it can lead to well-being in a school setting (Olsson et al., 2016). Recent studies indicate positive associations between different sources of perceived social support and school performance (Azmitia, Cooper, \& Brown, 2009; Danielsen, Wiium, Wilhelmsen, \& Wold, 2010; Fernandes et al., 2018; Sterrett, Jones, McKee, \& Kincaid, 2011; Woolley, Kol, \& Bowen, 2009). Thus, positive affective bonds established among students and their families, teachers and peers influence psychic health and the development of individuals (Juliano \& Yunes, 2014). In this direction, researches announce that higher levels of social support are associated with life satisfaction in adolescents (Chu, Saucier, \& Hafner, 2010; Sarriera, Bedin, Abs, Calza, \& Casas, 2015; Ruiz et al., 2012).

The literature review made it possible to verify that good school performance and life satisfaction are indicative of the occurrence of resilience processes in students. These positive results emerge in conditions of risk evidenced in the family, school and community contexts. Therefore, it is important to investigate which internal and external risk and protection factors of students can influence school performance and life satisfaction, especially in the phase that corresponds to the last years of elementary school.
According to the Elementary Education Development Index (Ideb, 2017) obtained by the School Census, this period of the schooling cycle presents high rates of failure, abandonment and dropout. However, the final years of elementary education are poorly focused and there is a shortage of studies that allow the understanding of factors and mechanisms that lead students and teachers to enhance their personal and contextual resources in cases of adverse situations in the family, school and community environments. In view of the above, the present study investigated the association of risk and protection factors in school performance with life satisfaction of elementary school students. The predictors were exposure to risk factors, such as intraand extra-family violence in students' lives and Burnout Syndrome in teachers; and exposure to protective factors: social skills and perception of social support by family, peers, teachers and community of students.

\section{Method}

\section{Participants}

A predictive correlation study was performed with a sample selected by convenience. A total of 400 students aged between 11 and 17 years $(M=13.6$ years, $S D=1.22)$, participated in the study, including $220(55 \%)$ girls and $180(45 \%)$ boys who attended the 7 th $(n .=135 ; 33.8 \%)$, 8th $(n .=145 ; 36.3 \%)$ and 9th grades $(n .=120 ; 30.0 \%)$ of Elementary School, in four schools, two public and two private, located in the state of Rio de Janeiro. The sample of teachers was composed of 26 female participants aged between 19 and 54 years $(M=36.04$ years, $S D=$ 7.97), of which 14 were from private schools and 12 , from public schools. Most teachers taught Portuguese $(46.2 \%)$ and Mathematics (42,3\%) and others, Biology $(3.8 \%)$, Physics $(3.8 \%)$ and Writing $(3.8 \%)$, for the 7 th $(30.8 \%)$, 8th $(38,5 \%)$ and 9 th grades $(30.8 \%)$.

\section{Instruments}

Global Satisfaction With Life Scale in Adolescents (EGV-A). The instrument is composed of 10 items that seek to assess life satisfaction as a whole, such as "I like my life" and "When I think about my life as a whole I consider myself satisfied". The items are responded in a 5-point-Likert-like scale, ranging from not at all (1) to very much (5). It is a version adapted for adolescents by Segabinazi, Zanon, Zortea and Giacomoni (2010), from the scale originally designed for children by Giacomoni (2002). The internal consistency 
of the scale in the adaption study was 0.90 (Cronbach's Alpha) and in the current study, 0.89.

Brazilian Youth Questionnaire (QJBra, Phase II Version). It is an instrument used to examine risk and protection factors of adolescents and young people (14 to 24 years) from different contexts and from a low socioeconomic level. The questionnaire was developed by Dell'Aglio, Koller, Cerqueira-Santos and Colaço (2011) and contains 77 multiple-choice questions organized in different scales. In the present study, questions 31 (intra-family violence) and 62 (extra-family violence) were selected for the collection of risk factors ("yes") or absence ("no") of, for example, threat or humiliation, punching or beating and aggression with some object. For the protection factors we selected question 68 , which assesses community support (for example, "I feel that I belong to my community/neighborhood"), containing six items on a 5 -point-Likert-like-scale, ranging from never (1) to always (5). In the present research we found the internal consistency index of 0.80 (Cronbach's Alpha) for question 68 - community support.

Maslach Burnout Inventory (MBI). It is an instrument used for the evaluation of Burnout syndrome in workers, made available by the Mind Garden publisher (www.mindgarden.com), which owns the rights for the Maslach Burnout assessment inventories. The authors acquired the license (n. JODVZDGAQ) for application of the inventory and publication of the results. It was validated for a sample of Brazilian teachers of Elementary and High School and Higher Education by Carlotto and Câmara (2004). The instrument contains 22 items with answers distributed in a 5-point-Likert-like scale, raging from never (1) to daily (5). The items are distributed in three dimensions: exhaustion, which deals with feelings and behaviors that indicate exhaustion in relation to work; professional achievement, characterized by low personal fulfillment at work and tendency to self-evaluate negatively; depersonalization, when the professional treats his colleagues or people linked to his work in an insensitive way. In the study by Carlotto and Camara (2004) the following internal consistency indexes (Cronbach's Alpha) were found to be $0.88,0.82$ and 0.58 and, in this sample, equal to $0.86,0.87$ and 0.68 , respectively.

Social Skills Inventory for Adolescents (IHSA-Del-Prette). It is an instrument developed by Del Prette \& Del Prette (2009) to evaluate the social skills of adolescents from their self-reports on everyday situations. The version assessed by Leme,
Campos, Coimbra, and Del Prette \& Del Prette (2016) is composed by 36 items with responses distributed in a 5-point-Likert-like scale, ranging from never (0) to always (4). The inventory is formed by six factors, which in the study by Leme et al. (2016) obtained the following internal consistency indexes (Cronbach's Alpha): (1) Empathy $(\alpha=0.80$, "When a friend has a position contrary to mine, I can negotiate a solution that is good for both of us"); (2) Self-control ( $\alpha=0.73$, "Being unfairly criticized, I can respond without losing control"); (3) Civility ( $\alpha=0.75$, "When leaving a place, I say goodbye to people"); (4) Assertiveness $(\alpha=0.63$, "I can take the initiative to end the conversation (chat) with another person"); (5) Affective approach $(\alpha=0.68$, "When I have a crush on someone, I tell him or her in the first opportunity"); (6) Social Development ( $\alpha=0.61$, "In group work, I explain tasks to colleagues when necessary"). Concerning internal consistency, we found the following values in the present study: $0.74,0.73,0.48,0.72,0.74$ and 0.70 , respectively.

Scale of Social Support Perception (EPAS). This scale assesses the perception of social support of children and adolescents in relation to family and friends. It was developed by Vaux et al. (1986) and validated for the adolescent Brazilian population by Squassonie Matsukura (2014). It comprises 30 items distributed on a 6-point-Likert-like scale, ranging from (1) totally disagree to (6) totally agree. The instrument includes four subscales with the following internal consistency indices for the validation sample: family ( $\alpha=0.83$, "My family cares very much for me"); friends ( $\alpha=0.80$, "I feel very attached to my friends"); teachers ( $\alpha=0.80$, "I am greatly esteemed by my teachers"); others ( $\alpha=0.77$, "I am respected by most people"), and for this sample, presented the following internal consistency indices (Cronbach's Alpha): $0.80 ; 0.85 ; 0.89 ; 0.71$, respectively. Considering that the objective was to identify the influence of perception of social support in students, we did not use social support by others.

Questionnaire with demographic information of students and teachers. It is an instrument developed for the present study. It aims to obtain demographic data of students and teachers, such as age, sex and school grade that teaches the subject (for teachers).

\section{Procedures}

In accordance with Resolution 466/12 of the Brazilian National Health Council, the project was 
approved by the Research Ethics Committee of the University where the study was conducted (process $n$. suppressed). After handing in the Informed Consent Form (ICF) and the Term of Agreement (TA), signed by the legal guardians of the students and by the students themselves, data collection (average duration of 50 minutes) was conducted collectively in 26 classrooms, at the time previously agreed with the teachers.

Once data collection with the students was finished, and after teachers signed and handed in the ICF, data collection with their teachers was started (average duration of 50 minutes), which occurred in the teachers room and was administered collectively, at the schedule previously arranged. As inclusion criteria, we selected one teacher per classroom and those who taught the subjects that provided a higher frequency of contact with the class (e.g. Portuguese and Mathematics). When there was more than one teacher in this condition a draw was made. School performance was obtained by summing the grades of all subjects (Portuguese, English, Mathematics, History, Geography, Physics, Chemistry and Sciences), computed in the final results record with the pedagogical coordinators of the participating schools. This sum was divided by the total number of subjects, generating a general index called the final average, which ranged from 0.0 to 10.0 .

\section{Data Analysis}

Data analysis was performed with the software Statistical Package for the Social Sciences for Windows (SPSS, version 22.0). First, the data from the same teacher was repeated for the students in his or her class. Next, normality assumptions were tested and confirmed, and then, correlation between the variables was calculated (Pearson $r$ coefficient). To interpret the magnitude of correlation coefficients the following values were adopted: $<0.20=$ very low; $>0.20$ and $<0.40=$ low; $>0.40$ and $<0.70=$ moderate $>0.70$ and $<0.90$ $=$ high; $>0.90=$ very high $($ Bryman \& Cramer, 2003). Finally, the independence and multicollinearity assumptions were tested and confirmed for the two predictive models and, next, the hierarchical regression analysis (enter method) was performed. School performance and life satisfaction were the outcome variables in the models. Block 1 included the risk factors: exposure to violence (intra- and extra-family) and Burnout syndrome of teachers (emotional exhaustion, professional achievement and depersonalization). Block 2 included protection factors: social skills (empathy, self-control, civility, assertiveness, affective approach and social skills); and perception of social support (friends, family, teachers and community). A dummy variable was created to replace the non-metric independent variable, exposure to violence in the family and extra-family (yes $=1$; no $=0)$.

\section{Results}

Table 1 shows the correlations, mostly of low magnitude, between risk factors, protection factors and school performance and life satisfaction. In general, exposure to violence in the family was negatively associated with school performance (low correlation) and with life satisfaction (very low correlation). Exposure to extra-family violence correlated negatively with performance (low correlation). Burnout Syndrome in teachers (emotional exhaustion and professional achievement) was negatively associated with school performance (very low correlations). With the exception of the social skills assertiveness and affective approach, low correlations were found between all other social skills and perception of social support by peers, family, teachers and community with school performance. Satisfaction with life was positively associated with all social skills (low correlations) and types of social support (moderate correlations).

Data from the regression analysis are presented in Table 2. The prediction model for school performance indicates that, in Block 1 (risk factors), exposure to family violence and Burnout Syndrome (emotional exhaustion and poor professional achievement) account for $17 \%$ and predicts school performance negatively. The entrance of Block 2 (protection factors) contributes with $12 \%$ of the percentage of variation of school performance. The perception of social support from family and community are the only positive predictors of school performance.

The prediction model for life satisfaction indicates that the entry of Block 1 (risk factors) is not a significant model, explaining only $2 \%$ of the outcome. With the entry of Block 2 (protective factors), the predictive power increases to $52 \%$ of the total variation in life satisfaction. The social skills of self-control and the perception of social support from family and community are positive predictors of satisfaction with life.

Generally, data show that exposure to violence in the family environment is the most valuable predictor of student performance. The perception of social support from the family and the community are the predictors with higher values on life satisfaction. 
Table 1.

Correlations between Risk and Protection Factors and School Performance and Life Satisfaction of Students

\begin{tabular}{lccc}
\hline Variables & $M(S D)$ & School performance & Satisfaction with Life \\
\hline Risk factors & & & \\
Exposure to Violence & & $-0.37^{* *}$ & $-0.15^{* *}$ \\
$\quad$ Family & $0.40(0.49)$ & $-0.23^{* *}$ & -0.08 \\
$\quad$ Extra-family & & & \\
Burnout Syndrome & $23.32(8.46)$ & $-0.13^{* *}$ & -0.01 \\
$\quad$ Emotional exhaustion & $14.64(3.82)$ & $-0.12^{* *}$ & -0.02 \\
$\quad$ Professional Satisfaction & $8.79(4.49)$ & -0.01 & -0.01 \\
Depersonalization & & & \\
Protection factors & & & $0.37^{* *}$ \\
Social Abilities & $26.24(6.30)$ & $0.21^{* *}$ & $0.34^{* *}$ \\
Empathy & $15.24(6.14)$ & $0.20^{* *}$ & $0.35^{* *}$ \\
Self-control & $18.40(4.07)$ & $0.19^{* *}$ & $0.23^{* *}$ \\
Civility & $19.82(4.77)$ & 0.08 & $0.26^{* *}$ \\
Assertiveness & $11.33(4.59)$ & 0.08 & $0.30^{* *}$ \\
Affective approach & $10.84(3.90)$ & $0.13^{* *}$ & \\
Social resourcefulness & & & $0.32^{* *}$ \\
Perception of Social Support & $34.86(6.35)$ & $0.23^{* *}$ & $0.66^{* *}$ \\
Peers & $41.55(7.89)$ & $0.34^{* *}$ & $0.45^{* *}$ \\
Family & $28.13(7.82)$ & $0.28^{* *}$ & $0.47^{* *}$ \\
Teachers & $16.89(5.56)$ & $0.31^{* *}$ & \\
Community & & & \\
\hline
\end{tabular}

Note: $\mathrm{N} .=400$.

${ }^{*} p<0.05 .{ }^{* *} p<0.01$

\section{Discussion}

The aim of this study was to investigate the association of risk and protection factors with school performance and life satisfaction of elementary school students. The results of the correlation analyzes showed that students exposed to intra- and extra-family violence and whose teachers presented symptoms of burnout (emotional exhaustion and low professional achievement) had low school performance. These results corroborate with findings from other studies that found that both exposure to violence and teacher burnout syndrome lead to academic difficulties (Coohey et al., 2011; Devries et al., 2014; Diehl \& Marin, 2016; Hammig \& Jozkowski, 2013; Ho \& Cheung, 2010; Pacheco et al., 2014).
In line with other studies (Caemmerer \& Keith, 2015; Dias, Oliveira, Moreira, \& Rocha, 2015; Fernandes et al., 2018; Marturano \& Pizato, 2015), we found that students with more social skills and who perceived more social support from friends, family, teachers and the community showed better results in school performance. In fact, even though school performance is an assessment within the educational context, it is influenced by several relations between students, teachers and people present in other environments, such as family, community and by public policies (Dazzani et al., 2014). Thus, the study results highlight the importance of a dynamic and multifactorial understanding of school performance.

Also in relation to the evaluation in the school context, beyond academic questions, researchers have 
Table 2.

Hierarchical Regression for Predicting School Performance and Life Satisfaction of students

\begin{tabular}{|c|c|c|c|c|}
\hline \multirow{2}{*}{ Predictors } & \multicolumn{2}{|c|}{ School performance } & \multicolumn{2}{|c|}{ Satisfaction with life } \\
\hline & $B(\mathrm{SE})$ & $\beta$ & $B(\mathrm{SE})$ & $\beta$ \\
\hline \multicolumn{5}{|l|}{ Block 1 - Risk factors } \\
\hline \multicolumn{5}{|l|}{ Exposure to Violence } \\
\hline Family & $-0.86(0.13)$ & $-0.32^{* *+}$ & $-2.80(1.08)$ & $-0.14^{* *}$ \\
\hline Extra-family & $-0.19(0.14)$ & -0.07 & $-0.12(1.09)$ & -0.07 \\
\hline \multicolumn{5}{|l|}{ Burnout Syndrome } \\
\hline Emotional Exhaustion & $-0.02(0.01)$ & $-0.13^{*}$ & $-0.01(0.05)$ & -0.01 \\
\hline Professional Satisfaction & $-0.03(0.01)$ & $-0.10^{* \dagger}$ & $-0.01(0.12)$ & -0.01 \\
\hline Depersonalization & $-0.01(0.01)$ & -0.03 & $-0.01(0.10)$ & -0.01 \\
\hline$F$ & & $16.11^{* *}$ & & 1.87 \\
\hline$R^{2}$ & & 0.15 & & 0.01 \\
\hline$\Delta R^{2}$ & & 0.17 & & 0.02 \\
\hline \multicolumn{5}{|l|}{ Block 2 - Protection Factors } \\
\hline \multicolumn{5}{|l|}{ Social skills } \\
\hline Empathy & $0.01(0.01)$ & 0.09 & $0.03(0.08)$ & 0.02 \\
\hline Self-control & $0.01(0.01)$ & 0.03 & $0.16(0.06)$ & $0.10^{*}+$ \\
\hline Civility & $0.01(0.01)$ & 0.02 & $0.20(0.11)$ & 0.08 \\
\hline Assertiveness & $0.01(0.01)$ & 0.02 & $0.10(0.08)$ & 0.05 \\
\hline Affective approach & $0.01(0.01)$ & 0.05 & $0.10(0.08)$ & 0.05 \\
\hline Social development & $0.01(0.01)$ & 0.03 & $0.03(0.11)$ & 0.01 \\
\hline \multicolumn{5}{|l|}{ Perception of Social Support } \\
\hline Friends & $0.02(0.01)$ & 0.07 & $0.05(0.06)$ & 0.03 \\
\hline Family & $0.02(0.01)$ & $0.12^{* *+}$ & $0.57(0.05)$ & $0.47^{* *+}$ \\
\hline Teachers & $0.01(0.01)$ & 0.08 & $0.09(0.05)$ & 0.07 \\
\hline Community & $0.03(0.01)$ & $0.15^{* *+}$ & $0.38(0.06)$ & $0.22^{* *+}$ \\
\hline$F$ & & $10.87^{* *}$ & & $30.68^{* *}$ \\
\hline$R^{2}$ & & 0.27 & & 0.52 \\
\hline$\Delta R^{2}$ & & 0.12 & & 0.52 \\
\hline
\end{tabular}

Note. $\mathrm{N}=400 . B=$ non-standard regression coefficient; $\mathrm{SE}=$ Standard error of the non-standard regression coefficient; $\beta=$ standard regression coefficient; $R^{2}=$ determination coefficient adjusted; $\Delta R^{2}=$ change coefficient of determination with the input of blocks.

${ }^{*} p<0.05 .{ }^{* *} p<0.01{ }^{\dagger}$ significant predictors that remained in the final model.

been interested in investigating other indicators of academic adjustment, such as students' satisfaction with life (Coimbra \& Fontaine, 2015). Understood as the cognitive dimension of well-being, satisfaction with life can evidence the way students face adversities in their daily lives in subjective, interpersonal, and affective terms (Long \& Huebner, 2014). In this sense, the results of the present study are in line with other studies that indicated that exposure to family violence negatively influences life satisfaction (Silva \& Dell'Aglio, 2016), while social skills and perceptions of social support increase their levels (França-Freitas et al., 2017; Sarriera et al., 2015), suggesting the amortizing and protective effect of the mentioned variables. In addition, according to the literature (Berger et al., 2011; Long \& Huebner, 2014), the results showed that students with better school results had higher levels of satisfaction with life. 
Regarding the results of the regression analyzes for school performance, exposure to violence in the family was the variable with greater weight in Block 1 , indicating that the more experiences of violence in the family, the lower the students' school performance. These findings are in line with previous studies that have shown that children and adolescents who experience intra-family violence tend to have lower school performance compared to those who have not been mistreated (Coohey et al., 2011; Devries et al., 2014; Hammig \& Jozkowski, 2013). The experiences of violence in the family environment interfere in the concentration, motivation and engagement of students in school activities (Pacheco et al., 2014).

Compared with extra-family violence, domestic violence has more devastating effects on the socioemotional and cognitive development of children and adolescents. The aggressions caused by family members tend to generate more suffering for the victims insofar as the family space is the one in which love, protection and security are sought socially (Mrug, Loosier, \& Windle, 2008). In addition, research suggests that adolescents exposed to violence in the family are more vulnerable to violence in other contexts, such as bullying episodes in school and community (Ho \& Cheung, 2010). Maltreatment in the family context can also lead to behavioral disorders and/or physical and psychological pathologies with effects in other phases of the life cycle (Hammig \& Jozkowski, 2013; Pacheco et al., 2014).

The results indicated that the dimensions emotional exhaustion and poor professional achievement of teachers were negative predictors of students' academic performance. These results are corroborated by the literature that identified that teachers' Burnout Syndrome may compromise the way educators perform daily tasks, harming their professional competence, the teaching-learning process (Diehl \& Marin, 2016; Koga et al., 2015) and the quality of the teacher-student relationship (Ackar et al., 2016). Thus, there are indications that the Burnout Syndrome can be a risk factor in the school context and that without the incidence of protective factors, it may compromise resilience processes that emerge through the quality of the relationship between teachers and good student performance (Juliano \& Yunes, 2014).

The entry of Block 2 (protective factors) contributed to the explanation of school performance. According to other studies, the perception of family social support was positively associated with good school performance (Azmitia et al., 2009; Fernandes et al., 2018; Woolley et al., 2009). The affective bonds established with family members provide feelings of security, are associated with higher levels of well-being and lower rates of behavioral and emotional problems, and can help students cope with demands in the school context. (Azmitia et al., 2009; Fernandes et al., 2018; Woolley et al., 2009). The affective bonds established with family members provide feelings of security, are associated with higher levels of well-being and lower rates of behavioral and emotional problems, and can help students cope with demands in the school context (Alves \& Dell’Aglio, 2015; Olsson et al., 2016).

The perception of social support from the community was also a positive predictor of school performance. Scientific evidence indicates that the perception of social support of friends by adolescents tends to increase with age (Squassoni \& Matsukura, 2014). These data suggest that people present in contexts other than family and school can have a positive effect on students' school performance. Positive interpersonal relationships established, for example, with community, neighborhood, and nongovernmental organizations may generate protective factors (Sterrett et al., 2011). It should be noted that such relationships may be protective contexts more often when interactions between students and family members and peer group are characterized by lack of affect and permeated by violence and discrimination (Sterrett et al., 2011). However, the perception of social support by the community is still under-explored and its association with school outcomes needs to be further investigated.

A second prediction model was tested for students' satisfaction with life. The data indicated that the risk factors did not represent a significant group. On the other hand, the protective factors were the ones that explained the higher percentage of the satisfaction variance, and the perception of social support from the family and the community were the variables with greater weight. As mentioned previously, the perception of social support of the family is not only correlated with school success, but also contributes to higher levels of satisfaction with life (Chu et al., 2010; Sarriera et al., 2015).

Studies show higher levels of satisfaction with life in adolescents who live with family members who express affectivity, have good communication, and establish limits in a non-coercive way (Chu et al., 2010). One hypothesis for such associations would be that in such contexts, adolescents feel more comfortable 
to express themselves and to talk freely about their anguish and doubts. This way, family members can meet the specific needs of children, favoring closeness and feelings of happiness (Olsson et al., 2016).

In the study by Ruiz et al. (2012), the perception of social support from the community led to higher levels of satisfaction with life. This suggests that adolescents who find positive interactions with peers and other adults in the community/neighborhood where they live, feel more supported to face adverse situations (Fariña, Arce, \& Novo, 2008) and more satisfied with their lives. In general, the results point to other contexts of socialization that may influence student well-being and should be the focus of preventive and protective interventions.

The social ability of self-control was a positive predictor of life satisfaction among students, which is in line with the literature (Ronen et al., 2016; Tangney, Baumeister, \& Boone, 2004). Self-control involves recognizing and expressing emotions and feelings, as well as calming down and tolerating frustrations. This social skill can help students cope with the demands and challenges that occur in the final years of elementary school, such as: greater number of disciplines; lower monitoring by teachers; conflicts with peers, pressure on the choice of affective relationships, and continuation of studies. Therefore, it can be assumed that students' ability to monitor and control their thoughts, feelings, and behaviors when faced with interpersonal and academic demands can contribute to a more satisfactory perception of everyday experiences.

It is important to emphasize that social skills were not predictive of school performance, diverging from other studies (Caemmerer \& Keith, 2015; Fernandes et al., 2018; Marturano \& Pizato, 2015). One hypothesis is that the relationship between social skills and school performance is mediated by the perception of social support. Some studies have found that the presence of social skills contributes to the ability of adolescents to identify and seek social support (Shin, Choi, Kim, \& Kim, 2010), as well as to present better school results (Roorda \& Koomen, 2011). In any case, future studies should investigate the indirect influences between social skills and school performance.

In the set of results of the present study it was possible to identify individual (self-control) and contextual protection factors (perception of social support from family and community) that can reduce and/or prevent the effects of risk factors on school performance and life satisfaction of students. The findings also showed the contradictory interfaces of the protective and risk functions of family and school contexts for students' lives (Juliano \& Yunes, 2014). It is a fact that protection environments favor healthy development contexts and enable resilience processes, as they help adolescents to seek relational spaces to cope with difficult situations of intra-family violence.

\section{Final considerations}

The results of this study contributed to a better understanding of some elements of resilience and vulnerability processes that act in student's daily contexts and exert influence on the dynamism of the student's school, affective and interpersonal aspects. Studies on resilience have emphasized that the identification of risk and protection factors must transcend individual characteristics and invest in understanding the interrelationships between the person and the context to which he or she belongs. However, in general, educational institutions infer that the good overall adjustment of students is based on academic results, mainly through school averages, to the detriment of the evaluation and promotion of socioemotional competences.

The limitations of the present study are: (1) data were collected from the school context, and it is important to extend the research to other systems, such as family and community; (2) the use of the cross-sectional design does not allow for the identification of changes in students' behavior during the final years of Elementary School, which would be possible using longitudinal research; (3) the school mean was used as a non-standard measure, which allowed a contextualized evaluation of the educational reality of the selected schools, but limits the comparison with other places.

Taking into account the limitations, future studies could: (1) include information obtained from other sources, such as family members and teachers; (2) to investigate other predictors of school performance and life satisfaction, such as school environment, community involvement, social skills of parents and teachers, and perceptions of school stressors; (3) investigate other dimensions of resilience processes in different risk situations to identify the direct and indirect relationships of risk and protection elements on student adjustment indicators; (4) propose preventive interventions and promote positive development in the school environment with students, their families and teachers. 


\section{References}

Ackar, A. M. N. E., Leme, V. B. R., Soares, A. B., \& Yunes, M. A. M. (2016). Correlações entre habilidades sociais educativas dos professores, Burnout e relação professor-aluno. Estudos e Pesquisas em Psicologia, 16(3), 873-891. Recuperado de: www.epublicacoes.uerj.br/ojs/index.php/revispsi/ article/view/32890

Alves, C. F., \& Dell'Aglio, D. D. (2015). Percepção de apoio social de adolescentes de escolas públicas. Revista de Psicologia da IMED, 7(2), 89-98. doi: 10.18256/2175-5027/psico-imed.v7n2p89-98

Azmitia, M., Cooper, C. R., \& Brown, J. R. (2009). Support and guidance from families, friends, and teachers in Latino early adolescents' math pathways. Journal of Early Adolescence, 29(1), 142 - 169. doi: $10.1177 / 0272431608324476$

Berger, C., Alcalay, L., Torretti, A., \& Milicic, N. (2011). Socio-emotional well-being and academic achievement: Evidence from a multilevel approach. Psicologia: Reflexão e Crítica, 24(2), 344-351. doi 10.1590/S0102-79722011000200016

Brasil. Ministério da Educação (2017). Índice da Educaşão Básica. Brasília: Ideb. Recuperado de: http://ideb. inep.gov.br/resultado

Bryman, A, \& Cramer, D. (2003). Analise de dados em ciências sociais. $3^{\mathrm{a}} \mathrm{Ed}$. Oeiras: Celta.

Caemmerer, J. M., \& Keith, T. Z. (2015). Longitudinal, reciprocal effects of social skills and achievement from kindergarten to eighth grade. Journal of School Psychology, 53(4), 265-281. doi:10.1016/j. jsp.2015.05.001

Carlotto, M. S., \& Câmara, S. G. (2004). Análise fatorial do Maslach Burnout Inventory (MBI) em uma amostra de professores de instituições particulares. Psicologia em Estudo (Maringá), 9(3), 499-505. doi: 10.1590/S1413-73722004000300018

Chu, P. S., Saucier, D. A., \& Hafner, E. (2010). Metaanalysis of the relationships between social support and well-being in children and adolescents. Journal of Social and Clinical Psychology, 29(6), 624-645. doi: 10.1521/jscp.2010.29.6.624

Coimbra, S., \& Fontaine, A. M. V. G. (2015). Resiliência e habilidades sociais: Reflexões conceituais e práticas para uma nova geração. Em Z. A. P. Del Prette, A. B. Soares, C. S. Pereira-Guizzo, M. F. Wagner, \& V. B. R. Leme (Orgs.), Habilidades sociais: Diálogos e intercâmbios sobre pesquisa e prática (pp. 186220). Novo Hamburgo, RS: Sinopsys.

Coohey, C., Rennera, L. M., Huab, L., Zhangc, Y. J., \& Whitneyd, S. D. (2011). Academic achievement despite child maltreatment: A longitudinal study. Child Abuse \& Neglect, 35(1), 688- 699. doi:10.1016/j. chiabu.2011.05.009

Danielsen, A. G., Wiium, N., Wilhelmsen, B. U., \& Wold, B. (2010). Perceived support provided by teachers and classmates and students' self-reported academic initiative, Journal of School Psychology, 48(3), 247-267. doi: 10.1016/j.jsp.2010.02.002.

Dazzani, M. V. M., Cunha, E. O., Luttigards, P. M., Zucoloto, P. C. S. V., \& Santos, G. L. (2014). Queixa escolar: Uma revisão crítica da produção científica nacional. Psicologia Escolar e Educacional, 18(3), 421428. doi:10.1590/2175-3539/2014/0183762

Del Prette, A., \& Del Prette, Z. A. P. (2009). Inventário de habilidades sociais para adolescentes (IHSA-Del Prette): Manual de aplicação, apuração e aplicação. São Paulo: Casa do Psicólogo.

Del Prette, Z. A. P., \& Del Prette, A. (2010). Social skills and behavior analysis: Historical proximity and new issues. Perspectivas em Análise do Comportamento, 1(2), 104-115. Recuperado de:http:/ /media. wix.com/ugd/89bfd6_ad8b815844a44ccfa667cb38495fe505.pdf

Dell'Aglio, D. D., Koller, S. H., Cerqueira-Santos, E., \& Colaço, V. F. R. (2011). Revisando o Questionário da Juventude Brasileira: Uma nova proposta. Em D. Dell'Aglio \& S. Koller (Orgs.), Adolescência e Juventude: Vulnerabilidade e contextos de proteção (pp. 259-270). São Paulo: Casa do Psicólogo.

Devries, K. M., Child, J. C., Allen, E., Walakira, E., Parkes, J., \& Naker, D. (2014). School violence, mental health, and educational performance in Uganda. Pediatrics, 133(1), 129-137. doi:10.1542/ peds.2013-2007

Dias, A., Oliveira, J. T., Moreira, P. A. S., \& Rocha, L. (2015). Percepção dos alunos acerca das estratégias de promoção do sucesso educativo e envolvimento com a escola. Estudos de Psicologia (Campinas), 32(2), 187-199. doi: 10.1590/0103-166X2015000200004 
Dieh, L., \& Marin, A. H. (2016). Adoecimento mental em professores brasileiros: Revisão sistemática da literatura. Estudos Interdisciplinares em Psicologia, 7(2), 64-85. doi: 10.5433/2236-6407.2016v7n2p64

Fariña, F., Arce, R., \& Novo, M. (2008). Neighborhood and community factors: Effects on deviant behavior and social competence. The Spanish Journal of Psychology, 11(1), 78-84. doi: 10.1017/ S1138741600004133

Fernandes, L. M., Leme, V. B. R., Elias, L. C. S., \& Soares, A. B. (2018). Preditores do desempenho escolar ao final do ensino fundamental: histórico de reprovação, habilidades sociais e apoio social. Temas em Psicologia, 26(1), 2015-228. doi: 10.9788/ TP2018.1-09Pt

França-Freitas, M. L. P., Del Prette, A., \& Del Prette, Z. A. P. (2017). Habilidades sociais e bem-estar subjetivo de crianças dotadas e talentosas. Psico-USF, 22(1), 1-12. doi: 10.1590/1413-82712017220101

Giacomoni, C. H. (2002). Bem-estar subjetivo infantil: Conceito de felicidade e construção de instrumentos para avaliação (Tese de doutorado). Universidade Federal do Rio Grande do Sul, Rio Grande do Sul. Disponível em: https://www.lume.ufrgs.br/bitstream_id/3889/000333187.pdf

Hammig, B., \& Jozkowski, K. (2013). Academic achievement, violent victimization, and bullying among U.S. high school students. Journal of Interpersonal Violence, 28(7), 1424-1436. doi: $10.1177 / 0886260512468247$

Ho, M. Y., \& Cheung, F. M. (2010). The differential effects of forms and settings ofexposure to violence on adolescents' adjustment. Journal of Interpersonal Violence, 25(7), 1309-1337. doi: $10.1177 / 0886260509340548$

Juliano, M. C. C., \& Yunes, M. A. M. (2014). Reflexões sobre rede de apoio social como mecanismo de proteção e promoção de resiliência. Ambiente \& Sociedade, 27(3), 135-152. doi: 10.1590/ S1414-753X2014000300009

Koga, G. K. C., Melanda, F. N., Santos, H. G., Sant'Anna, F. L., González, A. D., Mesas, A. E., \& Andrade, S. M. (2015). Fatores associados a piores níveis na escala de Burnout em professores da educação básica. Caderno de Saúde Coletiva, 23(3), 268-275. doi: 10.1590/1414-462X201500030121
Leme, V. B. R., Campos, J. R., Coimbra, S., A. Del Prette, \&Del Prette, Z. A. (2016). Inventário de habilidades sociais para adolescentes: Evidências de validade de constructo e confiabilidade. Psico, 47(3), 169178.doi: 10.15448/1980-8623.2016.3.20942

Long, R. F., \& Huebner, E. S. (2014). Differential validity of global and domain-specific measures of life satisfaction in the context of schooling. Child Indicators Research, 7(1), 671-694. doi: 10.1007. qs12187-013-9231-5

Marturano, E. M., \& Pizato, E. C. G. (2015). Preditores de desempenho escolar no $5^{\circ}$ ano do Ensino Fundamental. Psico, 46(1), 16-24. doi: 10.15448/1980-8623.2015.1.14850

Maslach, C., Schaufeli, W. B., \& Leiter, M. P. (2001). Job burnout. Annual Review Psychology, 52(1), 397-422. doi: 10.1146/annurev.psych.52.1.397

Masten, A. S. (2014). Global perspectives on resilience in children and youth. Child Development, 85(1), 6-20. doi: 10.1111/cdev.12205

Mrug, S., Loosier, P. S., \& Windle, M. (2008). Violence exposure across multiple contexts: Individual and joint effects on adjustment. American Journalof Orthopsychiatry, 78(1), 70-84.doi: 10.1037/0002-9432.78.1.70

Olsson, I., Hagekull, B., Giannotta, F., \&Ahalander, C. (2016). Adolescents and social support situations. Scandinavian Journal of Psychology, 31(1), 1-10. doi: 10.1111/sjop.12282

Pacheco, J. T. B., Irigaray, T. Q., Werlang, B., Nunes, M. L. T., \&Argimon, I. R. L. (2014).Childhood maltreatment and psychological adjustment: A systematic review. Psicologia: Reflexão \& Crítica, 27(4), 815-824. doi:10.1590/1678-7153.201427422

Perrenoud, P. (2003). Sucesso na escola: Só o currículo, nada mais que o currículo. Cadernos de Pesquisa, 119, 9-27. Recuperado de:http://publicacoes.fcc.org. br/ojs/index.php/cp/article/view/513/517

Ronen, T., Hamama, L., Rosenbaum, M., \& Mishely-Yarlap, A. (2016). Subjective well-being in adolescence: The role of self-control, social support, age, gender, and familial crisis. Journal of Happiness Studies, 17(1), 81-104. doi:10.1007/ s10902-014-9585-5

Roorda, D.L., \& Koomen, H.M.Y. (2011). The influence of affective teacher-student relationships 
on students' school engagement and achievement: A meta-analytic approach. Review of Educational Research, 81(4), 493-529.doi: 10.3102/0034654311421793

Ruiz, D. M., Díaz, A. P., Ferrer, B. M., \& Ochoa, G. M. (2012). Emotional and social problems in adolescents from a gender perspective. The Spanish Journal of Psychology, 15(3), 1013-1023. doi: 10.5209/rev_ SJOP.2012.v15.n3.39392

Sarriera, J. C., Bedin, L., Abs, D., Calza, T., \& Casas, F. (2015). Relationship between social support, life satisfaction and subjective well-being in Brazilian adolescents. Universitas Psychologica, 14(2), 459-474. doi: 10.11144/Javeriana.upsy14-2.rbss

Segabinazi, J. D., Giacomoni, C. H., Dias, A. C. G, Teixeira, M. A. P., \& Moraes, D. A. O. (2010). Desenvolvimento e validação preliminar de uma escala multidimensional de satisfação de vida para adolescentes. Psicologia: Teoria e Pesquisa, 26(4), 653659. doi: 10.1590/S0102-37722010000400009

Shin, H. S., Choi, H., Kim, M. J., \& Kim, Y. H. (2010). Comparing adolescents' adjustment and family resilience in divorced families depending on the types of primary caregiver. Journal of Clinical Nursing, 19(2), 1695-1706.doi: 10.1111/j.1365-2702.2009.03081.x.

Silva, D. G., \& Dell' Aglio, D. D. (2016).Exposure to domestic and community violence and subjective well-being in adolescents. Paidéia, 26(65), 299-305. doi: 10.1590/1982-43272665201603.

Silva, N. R., Bolsoni-Silva, A. T., Rodrigues, O. M. P. R., \& Capellini, V. L. M. F. (2015). O Trabalho do professor, indicadores de Burnout, práticas educativas e comportamento dos alunos: Correlação e predição. Revista Brasileira de Educação Especial, 2(3), 363-376. doi: 10.1590/S1413-65382115000300004

Squassoni, C. E., \& Matsukura, T. S. (2014). Adaptação transcultural da versão portuguesa do Social Support Appraisals para o Brasil. Psicologia: Reflexão \& Crítica, 27(1), 71-80. doi:10.1590/ S0102-79722014000100009

Sterrett, E. M., Jones, D. J., McKee, L. G., \&Kincaid, C. (2011). Supportive non-parental adults and adolescent psychosocial functioning: Using social support as a theoretical framework. American Journal of Community Psychoogy, 48(1), 284-295. doi: 10.1007/s10464-011-9429-y

Tangney, J. P., Baumeister, R. F., \& Boone, A. L. (2004). High self-control predicts good adjustment, less pathology, better grades, and interpersonal success. Journal of Personality, 72(2), 271-324. doi:10.1111/j.0022-3506.2004.00263.x.

Vaux, A., Philips, J., Holly, L., Thompson, B., Williams, D., \& Stewart, D. (1986). The Social Support Appraisals (SSA) scale: Studies of reliability and validity. American Journal of Community Psychology, 14(2), 195-220.doi: 0091-0562/86/0400-0195505.00/0

Woolley, M. E., Kol, K. L., \& Bowen, G. L. (2009). The social context of school success for latino middle school students: Direct and indirect influences of teachers, family, and friends. The Journal of Early Adolescence, 29(1), 43-70. doi: pdf/10.1177/027243160832447

Recebido em: 24/01/2018 Reformulado em: 14/06/2018; 02/08/2018 Aprovado em: 29/08/2018 
Sobre as autoras:

Ana Maria Nunes El Achkar é Mestre (2011) e Doutora (2016) em Psicologia pela Universidade Salgado de Oliveira (UNIVERSO/RJ). Atualmente realiza estágio de Pós-Doutorado na UNIVERSO/RJ com bolsa CAPES PNPD sob a supervisão da Dra. Maria Angela Mattar Yunes. Pesquisadora do Centro de Referência e Atenção às Famílias, Profissionais e Agentes Sociais - CRAFPAS/UNIVERSO em parceria com o CRAF/FURG.

ORCID: https://orcid.org/0000-0003-1628-1006

E-mail: anaelachkar@yahoo.com.br

Vanessa Barbosa Romera Leme é Psicóloga (Unesp-Bauru), Mestre (Psicologia do Desenvolvimento e Aprendizagem - Unesp-Bauru), Doutora (Psicologia - FFCLRP/USP) e Pós-doutorado (UFSCar). Pesquisadora do CNPq e Jovem Cientista do Nosso Estado (FAPERJ). Professora Adjunta no Departamento de Cognição e Desenvolvimento no Instituto de Psicologia e no Programa de Pós-Graduação em Psicologia Social (mestrado e doutorado) da Universidade do Estado do Rio de Janeiro (UERJ).

ORCID: https://orcid.org/0000-0002-9721-0439

E-mail: vanessaromera@gmail.com

Adriana Benevides Soares é Psicóloga, Mestre e Doutora em Psicologia, Universidade de Paris XI, França, Pesquisadora do CNPq, Cientista do Nosso Estado (FAPERJ). Pós-doutorado na Universidade Federal de São Carlos, UFSCar, São Carlos, SP. Professora permanente no Programa de Pós-Graduação em Psicologia da Universidade Salgado de Oliveira, UNIVERSO, Niterói, RJ e do Programa de Pós-Graduação em Psicologia da Universidade do Estado do Rio de Janeiro, UERJ, Rio de Janeiro, RJ.

ORCID: http://orcid.org/0000-0001-8057-6824

E-mail: adribenevides@gmail.com

Maria Angela Mattar Yunes é Psicóloga, Mestre em Psicologia, University of Dundee, Escócia, Doutora em Educação: Psicologia da Educação (PUC/SP), Pesquisadora do CNPq. Professora permanente no Programa de Pós-Graduação em Psicologia da Universidade Salgado de Oliveira, UNIVERSO, Niterói, RJ e colaboradora no Programa de Pós-Graduação em Educação na Universidade La Salle, UNILASALLE/Canoas. Coordenadora do Centro de Referência e Atenção às Famílias e Profissionais e Agentes Sociais- CRAFPAS/Universo.

ORCID: https://orcid.org/0000-0002-4653-3895

E-mail: mamyunes@gmail.com

Contato com as autoras:

Rua Marechal Deodoro, 263 - Centro

Niterói-RJ, Brasil

CEP: 24030-060

Psico-USF, Bragança Paulista, v. 24, n. 2, p. 323-335, abr./jun. 2019 